"Radio-sensitization of head and neck squamous cell carcinoma by a natural product derived podophyllotoxin"

\author{
Angel Resendez $z^{1 \ddagger}$, Dhanir Tailor ${ }^{1 \ddagger}$, Edward Graves ${ }^{1,2}$, Sanjay V. Malhotra ${ }^{1,2^{*}}$ \\ 'Department of Radiation Oncology, Stanford University School of Medicine, Palo Alto, \\ California 94304 \\ ${ }^{2}$ Department of Radiology, Canary Center at Stanford for Cancer Early Detection, Stanford \\ University School of Medicine, Palo Alto, California 94304
}

1. Synthesis of SU093

S-2

2. Experimental Methods

S-4

3. Combination Index $(\mathrm{Cl})$ calculations of individual and combined treatments

S-7

4. NMR characterization

S-9

5. References

S-10 


\section{Synthesis of SU093}

Amino alcohol precursor<smiles>COc1cccc(NCCO)c1</smiles>

To a solution of $m$-anisidine $(1.68 \mathrm{~mL}, 15 \mathrm{mmol})$ in dry dichloromethane $(40 \mathrm{~mL})$, pyridine $(1.57$ $\mathrm{mL}, 19.5 \mathrm{mmol}$ ) and 2-chloroethylchloroformate $(1.55 \mathrm{~mL}, 15 \mathrm{mmol}$ ) was slowly added. The mixture was stirred at room temperature for $2.5 \mathrm{~h}$ and washed with water $(15 \mathrm{~mL} \times 3)$, dried over anhydrous magnesium sulfate and concentrated under vacuum. The residue was dissolved in ethanol $(50 \mathrm{~mL})$, treated with sodium hydroxide $(2.40 \mathrm{~g}, 60 \mathrm{mmol})$ and heated at $90{ }^{\circ} \mathrm{C}$ for $4 \mathrm{~h}$. The mixture was dried under vacuum and the residue was dissolved in dichloromethane (25 $\mathrm{mL})$ then washed with water $(10 \mathrm{~mL} \times 3)$. Then the organic phase was dried over anhydrous magnesium sulfate and concentrated under vacuum as slurry of silica and purified by flash chromatography with hexane-ethylacetate gradient to give the title compound as dark oil (2.33 g, 93\%). ${ }^{1} \mathrm{H}$ NMR (400 MHz, Chloroform- $d$ ) $\delta 7.09$ (t, $J=8.1 \mathrm{~Hz}, 1 \mathrm{H}$ ), 6.28 (dddd, $J=16.7,8.1$, 2.3, $0.9 \mathrm{~Hz}, 2 \mathrm{H}), 6.20(\mathrm{t}, J=2.3 \mathrm{~Hz}, 1 \mathrm{H}), 4.05(\mathrm{~d}, J=5.9 \mathrm{~Hz}, 1 \mathrm{H}), 3.86-3.73(\mathrm{~m}, 5 \mathrm{H}), 3.25(\mathrm{q}, J$ $=5.1 \mathrm{~Hz}, 2 \mathrm{H}) .{ }^{13} \mathrm{C}$ NMR $(101 \mathrm{MHz}$, Chloroform- $d) \delta 160.80,149.46,130.05,106.32,102.90$, $99.11,61.13,55.10,46.07$.

Multicomponent synthesis of SU093<smiles>COc1ccc2c(c1)N(CCO)C1=C(C(=O)OC1)C2c1ccccc1</smiles>

A solution of amino alcohol component (2-(3-methoxyphenylamino) ethanol, $0.167 \mathrm{~g}, 1 \mathrm{mmol}$ ), benzaldehyde $(0.122 \mathrm{~mL}, 1.2 \mathrm{mmol})$, L-proline $(0.011 \mathrm{~g}, 0.1 \mathrm{mmol}, 10 \mathrm{~mol} \%)$, and tetronic acid $(0.120 \mathrm{~g}, 1.2 \mathrm{mmol})$ was prepared in anhydrous ethanol $(4 \mathrm{~mL})$ and the reaction mixture was refluxed for 3-4 h. Upon consumption of amino alcohol component and appearance of a fluorescent spot via TLC (9:1 of 50\% EtOAc/Hex:MeCN), a slurry of silica gel was prepared and purified by flash chromatography to give the SU093 compound as a off-white solid $(0.067 \mathrm{~g}$, 20\%). ${ }^{1} \mathrm{H}$ NMR (400 MHz, DMSO- $\left.d_{6}\right) \delta 7.25-7.15(\mathrm{~m}, 4 \mathrm{H}), 7.15-7.08(\mathrm{~m}, 1 \mathrm{H}), 6.96(\mathrm{dd}, J=$ 8.5, $0.8 \mathrm{~Hz}, 1 \mathrm{H}), 6.69(\mathrm{~d}, J=2.5 \mathrm{~Hz}, 1 \mathrm{H}), 6.56(\mathrm{dd}, J=8.5,2.4 \mathrm{~Hz}, 1 \mathrm{H}), 5.15-5.01(\mathrm{~m}, 3 \mathrm{H})$, 
$4.91(\mathrm{~s}, 1 \mathrm{H}), 3.84(\mathrm{dt}, J=14.6,4.8 \mathrm{~Hz}, 1 \mathrm{H}), 3.71(\mathrm{~s}, 6 \mathrm{H}) .{ }^{13} \mathrm{C} \mathrm{NMR}\left(101 \mathrm{MHz}\right.$, DMSO-d $\left.d_{6}\right) \delta$ $172.57,161.03,159.15,147.70,137.86,132.52$, 128.70, 128.02, 126.60, 119.31, 109.08, 100.85, 96.73, 66.30, 58.24, 55.71, 55.36, 48.32, 39.44. MS-ESI m/z calculated for $\mathrm{C}_{20} \mathrm{H}_{19} \mathrm{NO}_{4}$ $[\mathrm{M}+\mathrm{H}]^{+}: 337.130$, found 338.1. Mass analysis was carried using an Agilent 6490 iFunnel triple quadrupole (QQQ) mass spectrometer equipped with an Agilent 1290 infinity II UHPLC with the variable wavelength detector set at 254 and $310 \mathrm{~nm}$. Seperation was conducted on a ZORBAX C18 UHPLC column (Eclipse Plus, 2.1x $50 \mathrm{~mm}, 1.8 \mu \mathrm{m}$ particle size) using a 15 min binary gradient with a constant flow rate of $0.5 \mathrm{~mL} / \mathrm{min}$. Mobile Phase A: $0.1 \%$ formic acid and $4 \mathrm{mM}$ ammonium formate in water. Mobile phase B: $0.1 \%$ formic acid in acetonitrile. The following elution gradient was used: $2-9 \mathrm{~min}, 10-70 \% \mathrm{~B}, 9-13 \mathrm{~min}, 70 \% \mathrm{~B}, 13-15 \mathrm{~min}, 70-10 \% \mathrm{~B}$. The electrospray ionization source was operated in positive ion mode. 


\section{Experimental Methods}

Colony Formation assay: Cells were seeded at 600 cells per well in a 12-well plate (Corning). After $24 \mathrm{~h}$ of incubation, cells were treated with $0.5 \mu \mathrm{M}$ of SU093 and/or with different doses of radiation (2.5 or 5 Gy). Cells were allowed to incubate up to 10-14 days, then fixed, and stained with crystal violet according to previously described procedure..$^{25}$
control
0.1
0.5
$1.0 \mu \mathrm{M}$

\begin{tabular}{|c|c|c|c|}
\hline Replicate 1 & (") & (")" & ") \\
\hline Replicate 2 & (")" & "'" & "“' \\
\hline Replicate 3 & "'” & (")" & \\
\hline
\end{tabular}

Cell cycle analysis: The effect of SU093 and combined radiation treatment on cell cycle distribution was analyzed by flow cytometry after staining cells with propidium iodide (PI) according to previously published methods. ${ }^{26,27}$ Cells were seeded at $10^{5}$ per well, incubated for $24 \mathrm{~h}$, and treated with fresh media containing SU093 $(0.5 \mu \mathrm{M})$ for specific time periods. Both floating and adherent cells were collected, centrifuged, washed with 1X PBS twice, and fixed in $70 \%$ ethanol overnight at $4^{\circ} \mathrm{C}$. The fixed cells were incubated with $80 \mu \mathrm{g} / \mathrm{mL}$ RNase $A$ and 50 $\mu \mathrm{g} / \mathrm{mL} \mathrm{Pl}$ in saponin-EDTA solution for $30 \mathrm{~min}$ at $37^{\circ} \mathrm{C}$ and analyzed using a Guava easyCyte Flow Cytometer (Millipore, Burlington, MA). Percentage of cells in different phases of the cell cycle were computed for control and SU093 treated samples using FlowJo software.
SU093 + 5 Gy
5 Gy
SU093
control

\begin{tabular}{|l|l|l|l|}
\hline Replicate 1 & "’” & "” & \\
\hline Replicate 2 & "'” & & \\
\hline Replicate 3 & "'” & & \\
\hline
\end{tabular}

Annexin V Apoptosis Assay: For apoptosis analysis, cells were seeded and treated as previously described in the viability assay. At the end of each treatment, both floating and adhered cells were collected and processed for annexin V and PI staining using FITC Annexin V 
apoptosis detection kit (BD Pharmingen, San Jose, CA) following the manufacturer's protocol. The flow analysis for annexin $\mathrm{V}$ and PI stained cell was carried out by FACS using Guava easyCyte Flow Cytometer.

Scratch Migration Assay: For the in vitro migration assay, $10^{5}$ cells were seeded in at a 12 well plate and allowed to incubate until full confluency was achieved. Cells were then treated with either fresh media containing SU093 or media with vehicle (control wells) and respective cells received 5 Gy of radiation, and incubated for $24 \mathrm{~h}$. After the incubation period, each well was scratched using a pipette tip and washed with 1X PBS to remove detached cells, and fresh media containing mitomycin c was added. Initial wound $(0 \mathrm{~h})$ was recorded by photography at $100 \times$ magnification and allowed to incubate in between each subsequent recording $(6 \mathrm{~h}, 12 \mathrm{~h}$, and $24 \mathrm{~h}$ ). Percent migration was calculated by measuring the gap decrease for each time point in each condition with respect to its initial wound gap at $0 \mathrm{~h}$. This was calculated for each replicate $(n=3)$.

Immunoblotting: Both cell types were seeded in 100-mm culture dishes and treated with SU093 at $\sim 60 \%$ confluency for $48 \mathrm{~h}$. Both floating and attached cells were collected and lysed according to described published protocols. ${ }^{28}$ Cells were lysed with a M-PER ${ }^{\mathrm{TM}}$ Iysis solution (Thermo Scientific) on ice containing protease and phosphatase inhibitors. An Equal amount of protein was resolved on 10\% SDS-PAGE gel followed by transfer of PVDF membrane. Membranes were probed with respective primary and secondary antibodies followed by immunodetection using ECL system on IVIS Lumina Imaging System (Perkin Elmer, Waltham, $\mathrm{MA})$.

Immunofluorescence: Cells were grown on coverslips in 35-mm dish, washed with 1X PBS, fixed in $4 \%$ formaldehyde for $30 \mathrm{~min}$ and permeabilized with $0.3 \%$ Triton $\mathrm{X}-100$ for $15 \mathrm{~min}$. Cells were blocked with 10\% BSA (in 1X PBS) for 30 min, incubated with primary antibody for Nrf2 overnight at $4^{\circ} \mathrm{C}$ and then incubated with the secondary antibody Alexa Flour 488 (1:500, 
Invitrogen) for $1 \mathrm{~h}$, and counterstained with $300 \mathrm{nMDAPI}$. Cells were examined using a confocal fluorescence microscope (Inverted Zeiss LSM 880 laser scanning confocal microscope) at Canary Center Stanford.

Statistics: Statistical analysis was conducted with GraphPad Prism 5 software version 5. Quantitative data is presented as mean \pm SD. All experiments were repeated two-three times, and representative data are shown. Statistical significance of difference between control and treated group was determined by the unpaired Student t-test and $\mathrm{P}<0.05$ was considered significant (ns $=$ not significant, ${ }^{*}$ denotes $\mathrm{P}<0.05,{ }^{* *}$ denotes $\mathrm{P}<0.01,{ }^{* * *}$ denotes $\mathrm{P}<0.001$ ). 


\section{Combination Index-CompuSyn Calculations}

The combination index $(\mathrm{Cl})$ calculations were conducted using the CompuSyn software that is available for download at http://www.combosyn.com/index.html. Using these combination indexes, the synergism or additive effect of combined SU093 and ionizing radiation was evaluated for each HNSCC cell line.

A

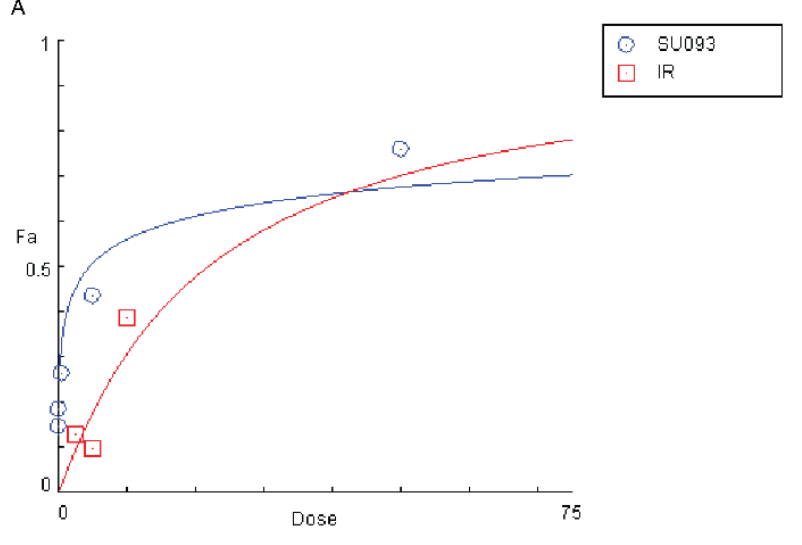

C

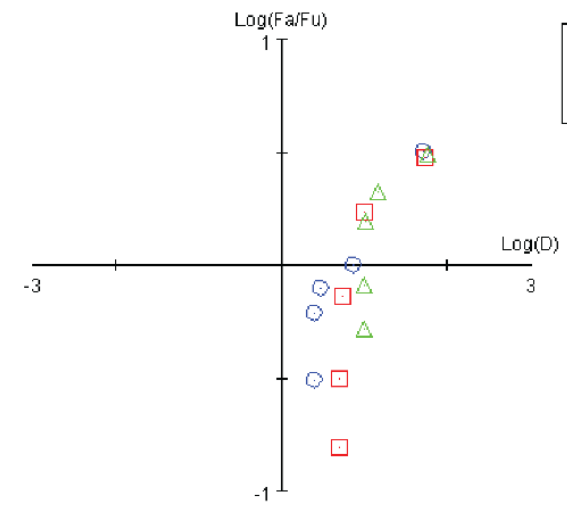

B

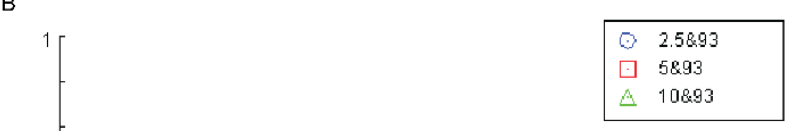

2.5893

口 5893

$\triangle \quad 10893$
]$^{D}$

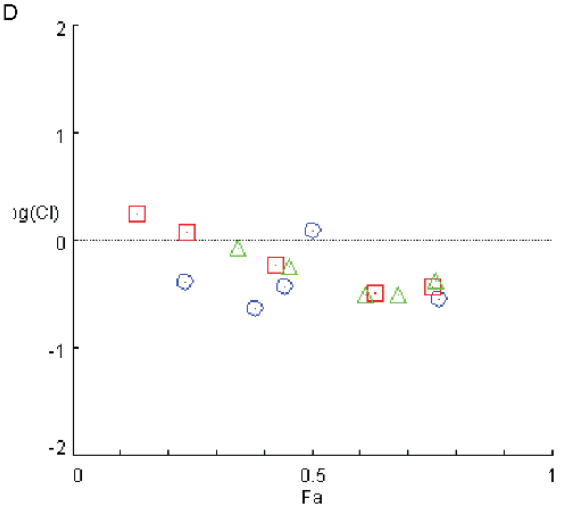

Figure S-1. Data acquisition of individual or combined dose of SU093 and ionizing radiation with respect to fractional inhibition ( $\mathrm{Fa}$ ) for FaDu cell line. A. Dose effect curve $\mathrm{B}$. dose effect curve for drug combination. C. median effect plot for drug combinations. D. logarithmic combination index plot. 
A

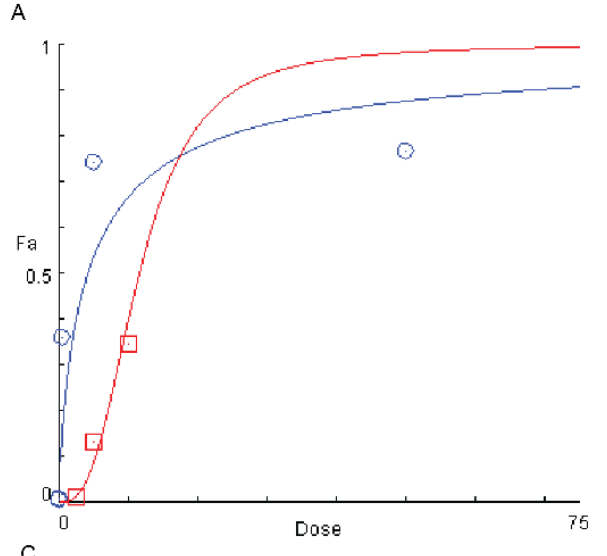

C

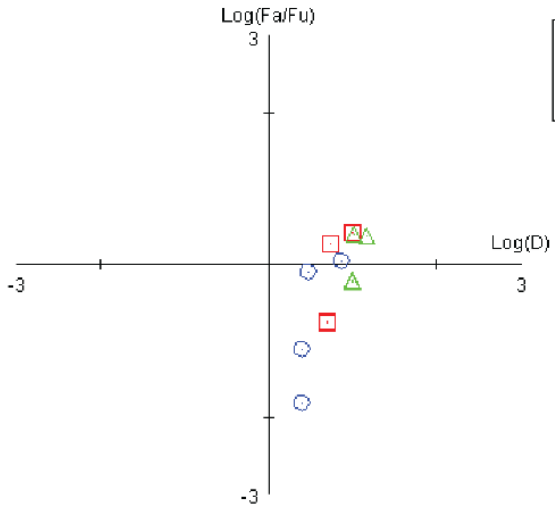

B
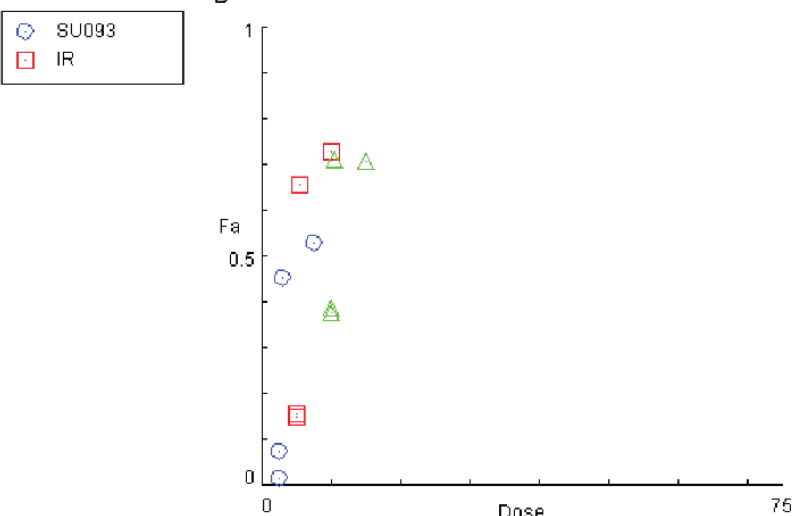

D
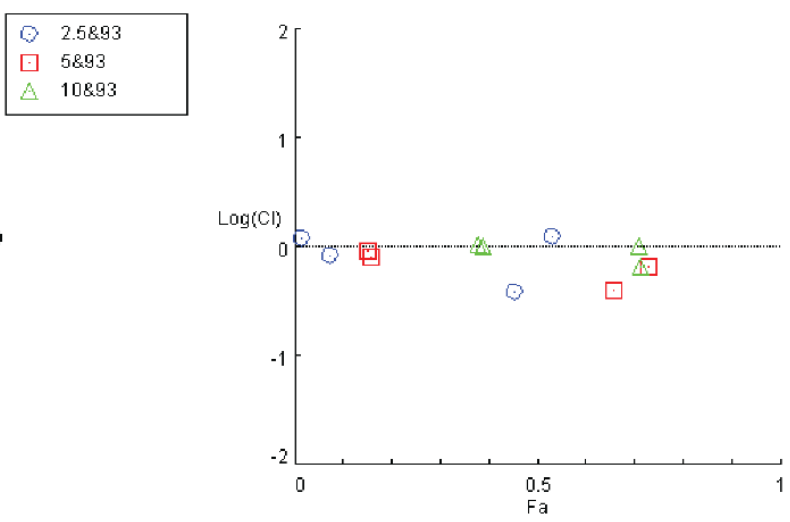

C 2.5893

口 5893

A 10893

Figure S-2. Data acquisition of individual or combined dose of SU093 and ionizing radiation with respect to fractional inhibition $(\mathrm{Fa})$ for $\mathrm{SCC}-25$ cell line. A. Dose effect curve B. dose effect curve for drug combination. C. median effect plot for drug combinations. D. logarithmic combination index plot. 


\section{NMR characterization}

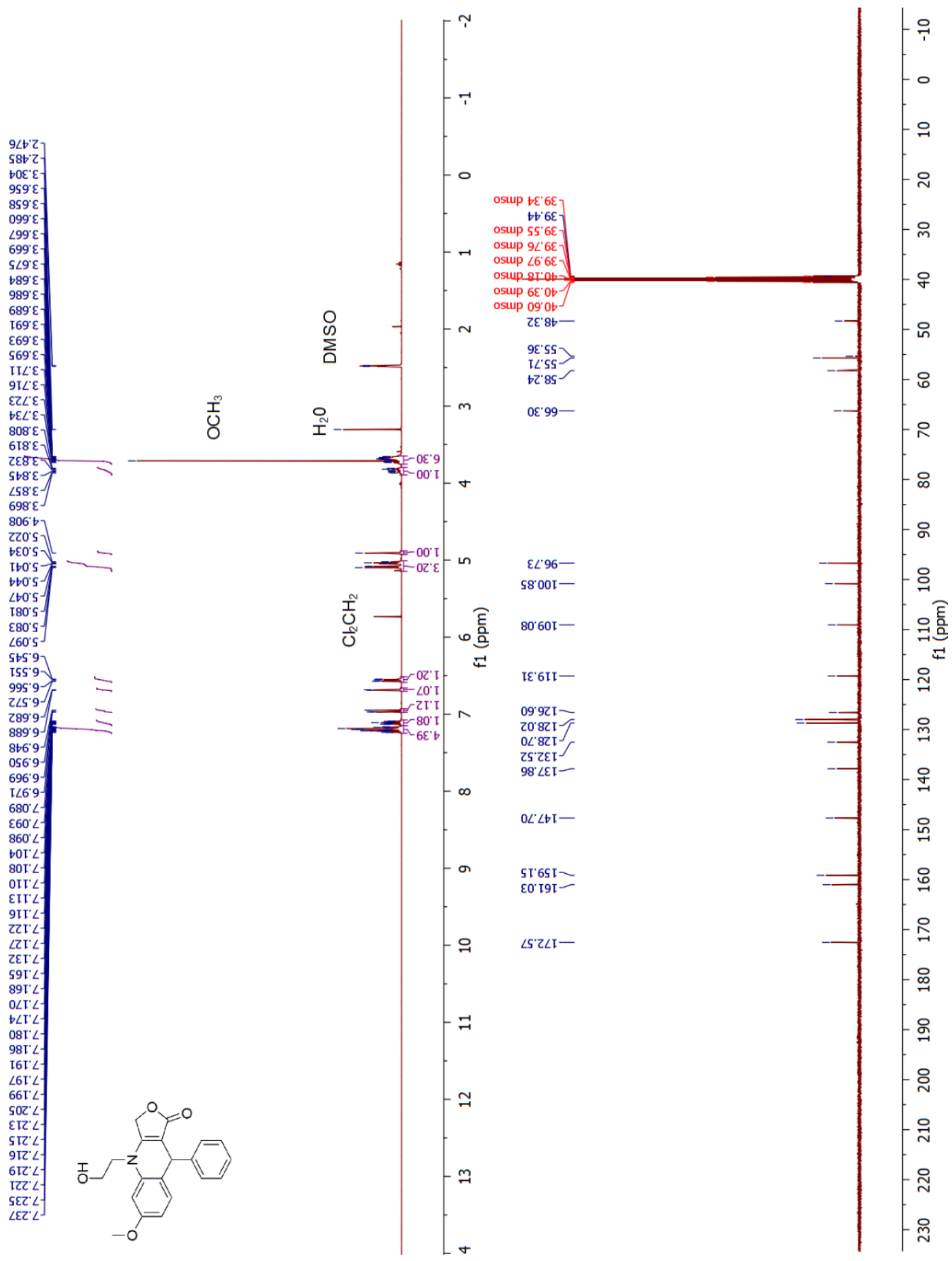

Figure S-3. ${ }^{1} \mathrm{H}$ - (top) and ${ }^{13} \mathrm{C}-\mathrm{NMR}$ (bottom) spectra of SU093. 


\section{References:}

25. Deep, G.; Oberlies, N. H.; Kro, D. J.; Agarwal, R., ldentifying the differential effects of silymarin constituents on cell growth and cell cycle regulatory molecules in human prostate cancer cells. International Journal of Cancer 2008, 123 (1), 41-50.

26.Nambiar, D.; Prajapati, V.; Agarwal, R.; Singh, R. P., In vitro and in vivo anticancer efficacy of silibinin against human pancreatic cancer BxPC-3 and PANC-1 cells. Cancer Letters 2013, 334 (1), 109-117.

27.Stan, S. D.; Zeng, Y.; Singh, S. V., Ayurvedic Medicine Constituent Withaferin A Causes G2 and M Phase Cell Cycle Arrest in Human Breast Cancer Cells. Nutrition and Cancer-an International Journal 2008, 60, 51-60.

28.Hahm, E.-R.; Singh, S. V., Withaferin A-induced apoptosis in human breast cancer cells is associated with suppression of inhibitor of apoptosis family protein expression. Cancer Letters 2013, 334 (1), 101-108. 